Article

\title{
Suborganizations of Institutions in Library and Information Science Journals
}

\section{Dalibor Fiala}

Department of Computer Science and Engineering, University of West Bohemia, Univerzitní 8, Plzeň 30614, Czech Republic; E-Mail: dalfia@kiv.zcu.cz; Tel.: +420-377-63-2429;

Fax: +420-377-63-2402

Received: 25 June 2013; in revised form: 19 August 2013 / Accepted: 26 September 2013 /

Published: 9 October 2013

\begin{abstract}
In this paper, we analyze Web of Science data records of articles published from 1991 to 2010 in library and information science (LIS) journals. We focus on addresses of these articles' authors and create citation and collaboration networks of departments which we define as the first suborganization of an institution. We present various rankings of departments (e.g., by citations, times cited, PageRank, publications, etc.) and highlight the most influential of them. The correlations between the individual departments are also shown. Furthermore, we visualize the most intense citation and collaboration relationships between "LIS" departments (many of which are not genuine LIS departments but merely affiliations of authors publishing in journals covered by the specific Web of Science category) and give examples of two basic research performance distributions across departments of the leading universities in the field.
\end{abstract}

Keywords: departments; ranking; PageRank; citations; collaborations

\section{Introduction and Related Work}

Bibliometric studies can roughly be conducted at three levels - individual researchers (micro-level), institutions (meso-level), and countries (macro-level). Of course, these "basic" levels can have their own sublevels (e.g., regions of a country) or they can be grouped into supralevels (such as continents). There have been many bibliometric analyses at various levels, but we can feel that at the meso-level those analyses have mainly concentrated on institutions as such or that they have not really been large-scale, i.e., involving tens or hundreds of thousands of items to analyze. This study tries to bridge 
this gap in the field of library and information science (LIS) by analyzing several tens of thousands of bibliographic records at the meso-level and concentrating on the suborganizations of institutions. An institution (or the primary organization) usually has an organizational structure comprising some suborganizations (level 1) that themselves may consist of other suborganizations (level 2). The depth of this hierarchy may vary-some institutions have a relatively flat structure, while other hierarchies may include suborganizations of even higher levels. A typical academic institution (a university) may be divided into faculties, schools, departments, laboratories, and research groups, which are difficult to capture in scientometric studies due to the inconsistent way they are present (or absent) in authors' addresses. As we will show later on, we will call level-1 suborganizations "departments" for the sake of simplicity. The main research questions of this study are the following: (a) Do Web of Science (WoS) data contain enough information to analyze the scientific performance and collaboration of the departments with which authors of journal articles in the LIS research area are affiliated? (hereafter called "LIS" departments); (b) What are the most intense citations and collaborations between "LIS" departments? and (c) Which "LIS" departments are the most highly ranked by various indicators based on publications from 1991-2010? Responses to these questions will be given in the next sections.

Bibliometric analysis of library and information science institutions has a long history in the United Kingdom. For instance, Bradley et al. [1] measured the publication patterns of the Department of Information Studies at the University of Sheffield, Holmes and Oppenheim [2] analyzed the citation impact of British LIS departments, and Oppenheim [3] ranked British LIS schools by citation impact. Seng and Willet [4] conducted a citation analysis of a small number of LIS departments in the UK and LIS departments in the UK were investigated by Webber [5]. British LIS departments were also analyzed webometrically - by Thomas and Willet [6] and by Arakaki and Willet [7]. As for other regions of the world, Aina and Mooko [8] analyzed a small set of top African LIS researchers and defined the centers of the African LIS research. Another tiny group of LIS publications was investigated by Herrero-Solana and Ríos-Gómez [9] to identify the most productive Latin American universities and departments. Meho and Spurgin [10] ranked American LIS schools by the visibility of their faculty in various databases and Yazit and Zainab [11] reported on the publication productivity in LIS of some Malaysian institutions. There have been two large-scale studies in which Yan and Sugimoto [12] explored citation patterns of various LIS institutions and He et al. [13] explored tens of thousands of LIS publications, but both of them remained at the institutional level. This study is the only large-scale one at the departmental level and the visualization tools used in this article are discussed by Shannon et al. [14].

\section{Data and Methods}

In November 2012 we manually queried the Web of Science web interface to obtain records of all articles published in the period 1991-2010 and indexed in the Social Sciences Citation Index in the research area "Information Science \& Library Science" (ISLS). We were interested in the "article" document type only. In this way, we acquired plain text metadata on 46,800 journal articles. (Saving to plain text took about 50 min because a maximum of 500 records can be saved at once by anyone with a Web of Science subscription.) These metadata typically include an article's title, journal name, 
volume, issue, pagination, and year as well as its authors' names, addresses, times cited count and some other information. An example of a journal record is presented in Figure 1. As we can see, only some of the cited references (CR) can be identified unambiguously - in this case with a digital object identifier (DOI). The remaining references can be identified using the volume, issue, and pagination or cannot be identified at all. To create a citation network from the article records retrieved (a basic, root, or seed set of articles), we need one more tool.

Figure 1. A sample journal article record.

PT J

AU Schreiber, M

AF Schreiber, Michael

TI A new family of old Hirsch index variants

SO JOURNAL OF INFORMETRICS

LA English

DT Article

DE Hirsch index; g-Index; Performance evaluation; Citations; Ranking; Generalized mean

ID SCIENTIFIC-RESEARCH OUTPUT; H-INDEX; EGGHES G; PHYSICISTS

AB The Hirsch index $h$ and the $g$ index proposed by Egghe as well as the $f$ index and the $t$ index

C1 Tech Univ Chemnitz, Inst Phys, D-09107 Chemnitz, Germany.

RP Schreiber, M (reprint author), Tech Univ Chemnitz, Inst Phys, D-09107 Chemnitz, Germany.

EM schreiber@physik.tu-chemnitz.de

CR Burrell QL, 2009, SCIENTOMETRICS, V79, P79, DOI 10.1007/s11192-009-0405-3

Egghe L, 2006, SCIENTOMETRICS, V69, P131, DOI 10.1007/s11192-006-0144-7

Egghe L., 2006, ISSI NEWSLETTER, V2, P8

Egghe L, 2008, J AM SOC INF SCI TEC, V59, P1304, DOI 10.1002/asi.20823

Hirsch JE, 2005, P NATL ACAD SCI USA, V102, P16569, DOI 10.1073/pnas.0507655102

Prathap G, 2006, CURR SCl INDIA, V91, P1439

Rousseau R., 2006, SIMPLE MODELS CORRES

Schreiber M, 2007, ANN PHYS-BERLIN, V16, P640, DOI [10.1002/andp.200710252, 10.1002/andp.20071025]

Schreiber M, 2010, J AM SOC INF SCl TEC, V61, P169, DOI 10.1002/asi.21218

SCHREIBER M, 2010, ANN PHYS BERLIN

Schreiber M, 2008, J AM SOC INF SCI TEC, V59, P1513, DOI 10.1002/asi.20856

Schubert A, 2007, SCIENTOMETRICS, V70, P201, DOI 10.1007/s11192-007-0112-x

Tol RSJ, 2009, SCIENTOMETRICS, V80, P317, DOI 10.1007/s11192-008-2079-7

Woeginger GJ, 2009, J AM SOC INF SCl TEC, V60, P1267, DOI 10.1002/asi.21061

NR 14

TC 2

Z9 2

PU ELSEVIER SCIENCE BV

PIAMSTERDAM

PA PO BOX 211, 1000 AE AMSTERDAM, NETHERLANDS

SN 1751-1577

J9 J INFORMETR

JIJ. Informetr.

PD OCT

PY 2010

VL 4

IS 4

BP 647

EP 651

DI 10.1016/j.joi.2010.05.002

PG 5

WC Information Science \& Library Science

SC Information Science \& Library Science

GA 647KA

UT WOS:000281616200020

ER 
Therefore, in the next step, we used the Web Services Lite application programming interface (API) to retrieve the records of articles citing the articles in the basic set. This API is available for free to anyone with a Web of Science subscription after registration. In total, we got 175,139 citing article records. The information contained in the citing article records is somewhat less abundant than in the plain text seed article records. In particular, any author address information is missing. On the other hand, citing article records are structured in a similar way as XML records. See Figure 2 for an example of a citing article record. In the example, an article with ID (UT) 000283981500004 is cited by an article with ID 000283981500001 . These IDs can then be matched with "UT WOS" in seed article records (see bottom of Figure 1) and, as a result, a complete citation network of the articles in the root set can be constructed. This citation graph had 94,836 edges, i.e., slightly over $54 \%$ of all citations were citations within the seed set.

Figure 2. A sample citing article record.

\begin{abstract}
<soap:Envelope xmlns:soap="http.//schemas.xmlsoap.org/soap/envelope/"〉
<soap:Body><ns2: citingArticlesResponse xmlns:ns2="http://woksearchlite.cxf.wokmws.thomsonreuters.com"> $<$ return $><$ parent $\rangle<$ authors $><$ label $>$ Authors $</$ label $><$ values $>$ Urquhart, $\mathrm{C}</$ values $>\langle$ values $>$ Thomas, $\mathrm{R}</$ values $>$ $\langle$ values $>$ Ovens, $\mathrm{J}\langle/$ values $>\langle$ values $>$ Lucking, $\mathrm{W}\langle/$ values $\rangle\langle$ values $>$ Villa, $\mathrm{J}</$ values $></$ authors $>$

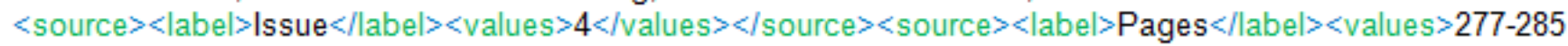

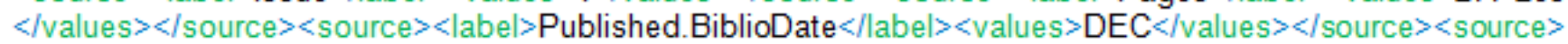
$<\mid$ abel $>$ Published. BiblioYear </label $><$ values $>2010</$ values $></$ source $><$ source $><\mid$ abel $>$ SourceTitle $</$ label $>$ $<$ values $>$ HEALTH INFORMATION AND LIBRARIES JOURNAL $</$ values $></$ source $>$

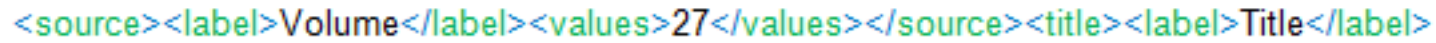

$<$ values $>$ Planning changes to health library services on the basis of impact assessment $\langle/$ values $\rangle\langle$ title $\rangle$

$<\mathrm{UT}>000283981500004</ \mathrm{UT}\rangle</$ parent $><$ query $\mid \mathrm{D}>54<$ /query $\mid \mathrm{D}><$ records $><$ authors $><$ label $\mid>$ Authors $</$ label $>$

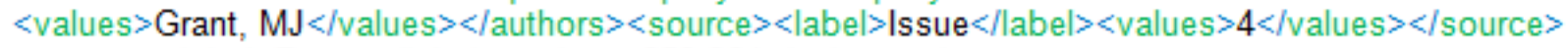

$<$ source $><\mid$ abel $>$ Pages $</$ label $><$ values $>259-261</$ values $></$ source $>$

$<$ source $><\mid$ abel $>$ Published.BiblioDate $</$ label $><$ values $>$ DEC $</$ values $></$ source $\rangle\langle$ source $>$

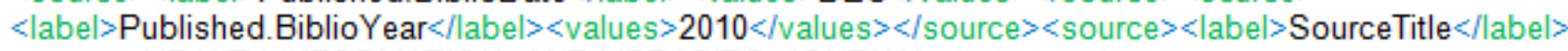

$<$ values $>$ HEALTH INFORMATION AND LIBRARIES JOURNAL $</$ values $></$ source $>$

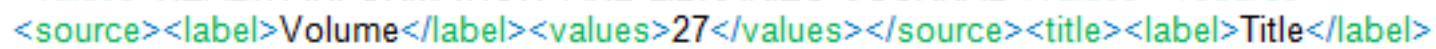

$<$ values $>$ Writing for publication: ensuring you find the right audience for your paper $</$ values $></$ title $>$

$\langle$ UT $>000283981500001</$ UT $></$ records $><$ recordsFound $>1</$ recordsFound $><$ recordsSearched $>3126432$

$</$ recordsSearched $></$ return $></$ ns2: citingArticlesResponse $></$ soap:Body $\rangle</$ soap:Envelope $>$
\end{abstract}

Since this paper is concerned with departments, the research depends on the extent to which affiliations and addresses of article authors are systematically present in the records we analyzed. There is no genuine affiliation information in the records, but there is often information on authors' addresses denoted with $\mathrm{C} 1$ and RP like in Figure 1. RP means a "reprint address", which is the address of the corresponding author (usually, but not always, the first author), and $\mathrm{C} 1$ is a field containing authors' addresses. Reprint and "normal" addresses may sometimes be the same, for instance when there is one author only. In total, almost $88 \%$ of publications had some address information associated with them and $65 \%$ had both reprint and normal address. $85 \%$ of publications had a reprint address and $68 \%$ had one normal address at least, but the latter percentage was quite different in various years under study as can be seen from Figure 3. While the share of publications with some address information has been about $90 \%$ throughout the period, the number of publications with one normal address at least has only had a similar share since 1998. Before 1998 there was a high percentage of publications having a reprint but no normal address (from $45 \%$ to $70 \%$ ), but this was almost negligible 
in later years and so was the number of articles having a normal address but no reprint address in the whole period 1991-2010.

Figure 3. Numbers of publications with different types of addresses.

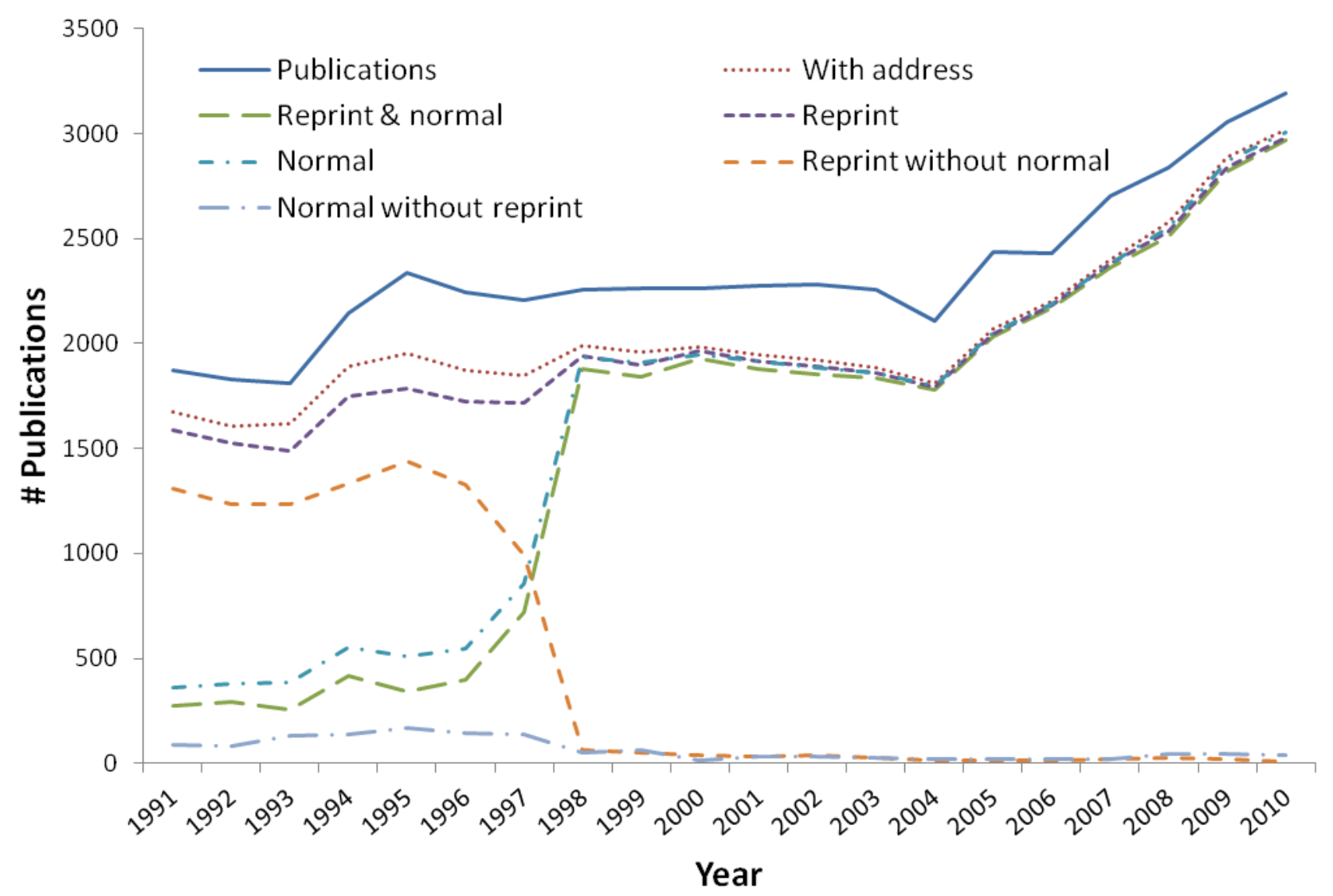

As can be seen in Figure 1, addresses have a relatively clear structure starting with an institution followed with suborganizations (from bigger to smaller ones) and ending with a city and a country. Organizations (institutions) and suborganizations are written using standardized abbreviations and are delimited with commas as are cities and countries. In our experience, reprint addresses often include also other information such as street names and numbers or state or province names, etc. This additional information can distort the common address pattern "institution, suborganizaiton1, ..., suborganizationN, city (+ZIP), country", but based on our experiments with random address samples and a manual checking of the pattern correctness, the pattern is violated in a few percent of cases even if reprint addresses are included. As a result, we made an approximation and considered all addresses in all publications in the period 1991-2010 as having an institution as their first item, a city and a country as their last item, and suborganizations in between. The number of suborganizations can vary as shown in Table 1. In the data under study, an institution (main organization) can have up to seven suborganizations associated with it, but most affiliations consist of an institution and its suborganization. Thus, before all the experiments whose results will be reported in the next section, we retained suborganization 1 in each address and discarded the other suborganizations of higher levels. We will call the couple "institution; suborganization 1" a "department" because this is typically what is represented by that. 
Table 1. Examples of various suborganizations of an institution.

\begin{tabular}{lccc}
\hline Organization & Suborganization 1 & Suborganization 2 & Suborganization 3 \\
\hline Indiana Univ & & & \\
Indiana Univ & Sch Lib \& Informat Sci & & \\
Indiana Univ & Sch Business & Decis \& Informat Syst Dept & \\
Indiana Univ & Sch Med & Dept Med & Div Gen Med \& Geriatr \\
\hline
\end{tabular}

\section{Results and Discussion}

The citation graph of departments we obtained had 18,291 nodes and 154,744 edges. The graph is directed and the edges are weighted with an average weight of 2.62 per edge. The total sum of edge weights in the graph $(404,755)$ is the total number of citations between departments. In Table 2 we can see the departments that received the most citations: "Indiana Univ; Sch Lib \& Informat Sci", "Leiden Univ; Ctr Sci \& Technol Studies", and "Univ Sheffield; Dept Informat Studies". However, the numbers of publications by which the departments are represented (see the last column in Table 2) vary significantly so "Leiden Univ; Ctr Sci \& Technol Studies" with 3722 citations and 84 publications is actually relatively more cited than "Indiana Univ; Sch Lib \& Informat Sci" with 4334 citations and 243 publications (44 citations per publication compared to 18). But the measure of citations per publication is obviously biased towards departments with fewer publications. For instance, the relatively most cited department in Table 2 is "Lib Hungarian Acad Sci; Bibliometr Serv" (position 33) with 165 citations per publication.

As far as the citations between individual departments are concerned, we can see the most intense of them in Figure 4. The size of nodes is based on the "times cited" (see below for an explanation) of a department and the thickness of edges depends on the number of citations from one department to another. We can notice that there are two big components - one centred around "Wolverhampton Univ; Sch Comp \& Informat Technol" and the other one around "Penn State Univ; Sch Informat Sci \& Technol". The most intense citations as such are those from "Wolverhampton Univ; Sch Comp \& Informat Technol" to "Indiana Univ; Sch Lib \& Informat Sci", "Victoria Univ Wellington; Sch Commun \& Informat Management", and "Univ Western Ontario; Fac Informat \& Media Studies". There are also intra-institutional citations such as from "Wolverhampton Univ; Sch Comp \& Informat Technol" to "Wolverhampton Univ; Sch Comp \& Informat Sci" or from "Penn State Univ; Coll Informat Sci \& Technol" to "Penn State Univ; Sch Informat Sci \& Technol”, but these may sometimes be self-citations of departments that changed their names or whose names are used inconsistently. These errors are inherent in the Web of Science data and they could be removed only by means of a huge amount of manual effort. In total, we found that $4.3 \%$ of all citations were intra-institutional. 
Table 2. Top 40 "library and information science (LIS)" departments by citations.

\begin{tabular}{|c|c|c|c|}
\hline & Department & Citations & Publications \\
\hline 1 & Indiana Univ; Sch Lib \& Informat Sci & 4334 & 243 \\
\hline 2 & Leiden Univ; Ctr Sci \& Technol Studies & 3722 & 84 \\
\hline 3 & Univ Sheffield; Dept Informat Studies & 3606 & 195 \\
\hline 4 & Rutgers State Univ; Sch Commun Informat \& Lib Studies & 3413 & 144 \\
\hline 5 & Penn State Univ; Sch Informat Sci \& Technol & 3361 & 56 \\
\hline 6 & Univ Maryland; Robert H Smith Sch Business & 3013 & 52 \\
\hline 7 & Univ Minnesota; Carlson Sch Management & 2835 & 71 \\
\hline 8 & Univ Tennessee; Sch Informat Sci & 2661 & 118 \\
\hline 9 & Drexel Univ; Coll Informat Sci \& Technol & 2288 & 101 \\
\hline 10 & Univ Tampere; Dept Informat Studies & 2285 & 96 \\
\hline 11 & City Univ London; Dept Informat Sci & 2162 & 192 \\
\hline 12 & Univ Western Ontario; Fac Informat \& Media Studies & 2125 & 138 \\
\hline 13 & Wolverhampton Univ; Sch Comp \& Informat Technol & 2068 & 109 \\
\hline 14 & Univ British Columbia; Fac Commerce \& Business Adm & 1821 & 26 \\
\hline 15 & Univ Illinois; Grad Sch Lib \& Informat Sci & 1710 & 167 \\
\hline 16 & Queens Univ; Sch Business & 1651 & 24 \\
\hline 17 & Univ N Carolina; Sch Lib \& Informat Sci & 1630 & 102 \\
\hline 18 & Harvard Univ; Sch Med & 1516 & 143 \\
\hline 19 & Univ Georgia; Terry Coll Business & 1484 & 38 \\
\hline 20 & Florida State Univ; Coll Business & 1447 & 36 \\
\hline 21 & Univ Virginia; Mcintire Sch Commerce & 1413 & 18 \\
\hline 22 & Syracuse Univ; Sch Informat Studies & 1273 & 162 \\
\hline 23 & Georgia State Univ; Coll Business Adm & 1266 & 24 \\
\hline 24 & Univ Calif Irvine; Grad Sch Management & 1261 & 25 \\
\hline 25 & Univ Wisconsin; Sch Lib \& Informat Sci & 1195 & 71 \\
\hline 26 & Royal Sch Lib \& Informat Sci; Dept Informat Studies & 1158 & 31 \\
\hline 27 & Univ Pittsburgh; Sch Informat Sci & 1150 & 84 \\
\hline 28 & Univ So Calif; Marshall Sch Business & 1139 & 28 \\
\hline 29 & City Univ Hong Kong; Dept Informat Syst & 1064 & 64 \\
\hline 30 & Univ N Texas; Sch Lib \& Informat Sci & 1053 & 60 \\
\hline 31 & Univ Calif Los Angeles; Grad Sch Educ \& Informat Studies & 1015 & 42 \\
\hline 32 & Univ S Florida; Coll Business Adm & 992 & 17 \\
\hline 33 & Lib Hungarian Acad Sci; Bibliometr Serv & 991 & 6 \\
\hline 34 & Katholieke Univ Leuven; Steunpunt O\&o Stat & 984 & 20 \\
\hline 35 & Univ Arkansas; Sam M Walton Coll Business & 973 & 11 \\
\hline 36 & Florida State Univ; Sch Informat Studies & 971 & 53 \\
\hline 37 & Csic; Cindoc & 966 & 32 \\
\hline 38 & Georgia State Univ; Dept Comp Informat Syst & 966 & 27 \\
\hline 39 & Univ Wisconsin; Sch Lib \& Informat Studies & 946 & 74 \\
\hline 40 & Univ N Carolina; Kenan Flagler Business Sch & 926 & 13 \\
\hline
\end{tabular}


Figure 4. Most intense citations between "LIS" departments.

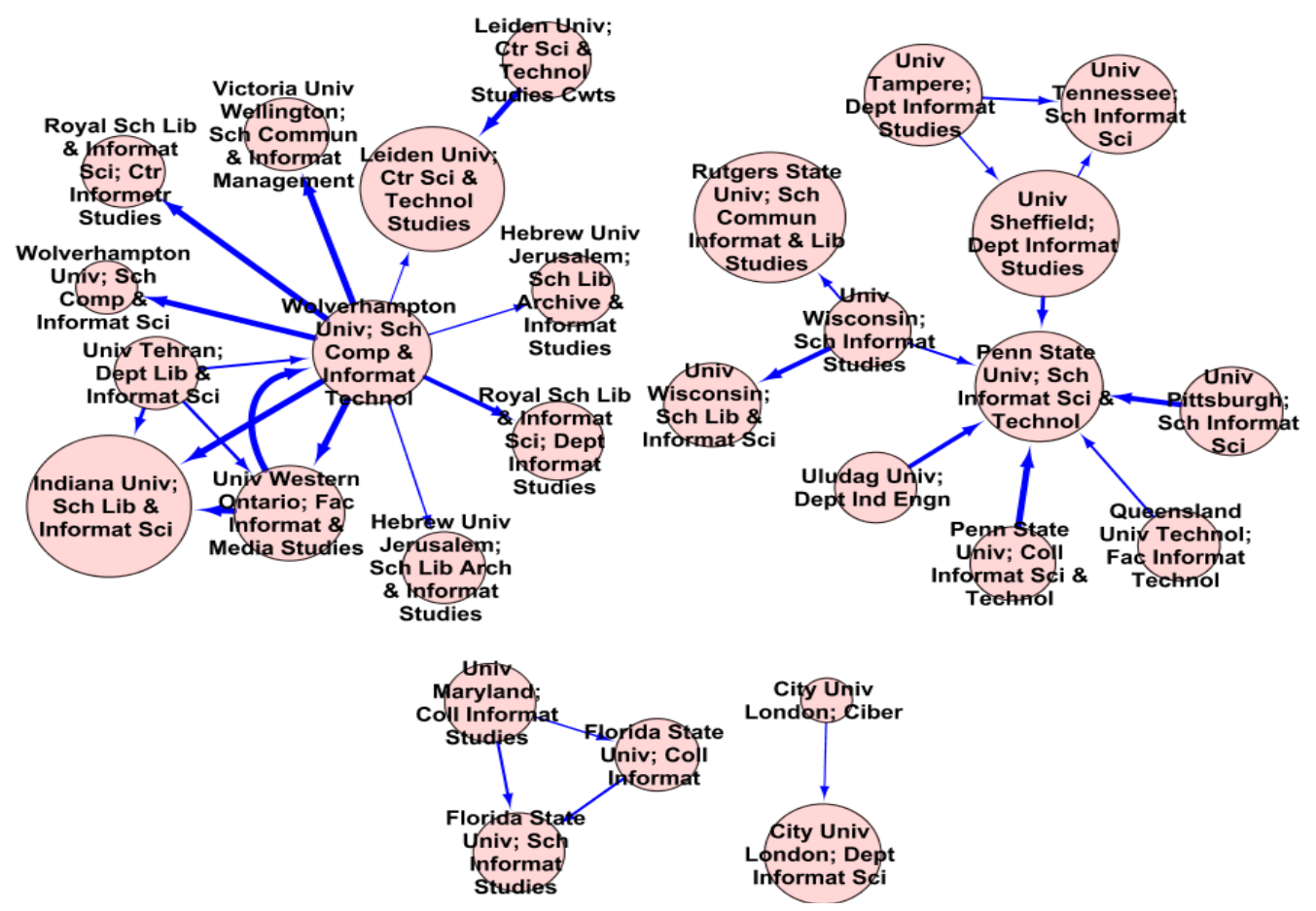

The citations shown in Table 2 are based on the citation graph of departments, which was generated from the core 46,800 publication records retrieved. Citations from publications outside of this core are not counted in, but they are included in the "Times Cited" indicator which is present in each publication record retrieved (TC in Figure 1). The ranking of departments by times cited looks different than that in Table 2 and the top departments are presented in Table 3. The best three departments are "Univ Minnesota; Carlson Sch Management", "Harvard Univ; Sch Med", and "Univ Maryland; Robert H Smith Sch Business". Again, departments with fewer publications often have higher times cited counts. An extreme case is "Univ So Calif; Knowledge Syst Lab" with one publication only and the largest times cited in Table 3. Note that the times cited count is not always greater than or equal to citations because both indicators are based on different citation graphs-the citation graph of articles and the citation graph of departments, respectively. Imagine a department affiliated with one article only that is merely cited once from an article with which three distinct departments are affiliated. In that case the cited department's times cited count is 1 and its citations indicator is 3. Thus the ranks of individual departments in both rankings can differ significantly. For example, "Univ So Calif; Knowledge Syst Lab" is ranked 10th by times cited but 396th by citations or "Lib Hungarian Acad Sci; Bibliometr Serv" is 33th by citations but 155th by times cited. Anyway, the interpretation may be that "Univ So Calif; Knowledge Syst Lab" is relatively more cited by researchers from other scientific fields than from the community of library and information science whereas "Lib Hungarian Acad Sci; Bibliometr Serv" is relatively more cited from within the community than from outside of it. There is also one highly ranked "department" by times cited, namely "The Scientist; 3600 Market St", which is wrongfully identified as such from frequent addresses associated with "The Scientist" journal articles in WoS data and which is ranked very low by citations. Nevertheless, the correlation between the department rankings by citations and by times cited is still rather high as will be shown later on. By the way, many of the present departments are not genuine LIS departments, 
but are affiliations of authors publishing in journals categorized as ISLS by WoS showing the multidisciplinarity of this field. On the other hand, some LIS research is also published in other WoS categories not covered by this study.

Table 3. Top 40 "LIS” departments by times cited.

\begin{tabular}{|c|c|c|c|}
\hline & Department & Times Cited & Publications \\
\hline 1 & Univ Minnesota; Carlson Sch Management & 4756 & 71 \\
\hline 2 & Harvard Univ; Sch Med & 4051 & 143 \\
\hline 3 & Univ Maryland; Robert H Smith Sch Business & 3860 & 52 \\
\hline 4 & Indiana Univ; Sch Lib \& Informat Sci & 3475 & 243 \\
\hline 5 & Queens Univ; Sch Business & 3070 & 24 \\
\hline 6 & Rutgers State Univ; Sch Commun Informat \& Lib Studies & 2950 & 144 \\
\hline 7 & Univ Virginia; McIntire Sch Commerce & 2942 & 18 \\
\hline 8 & The Scientist; 3600 Market St & 2922 & 569 \\
\hline 9 & Univ Sheffield; Dept Informat Studies & 2761 & 195 \\
\hline 10 & Univ So Calif; Knowledge Syst Lab & 2696 & 1 \\
\hline 11 & Leiden Univ; Ctr Sci \& Technol Studies & 2673 & 84 \\
\hline 12 & Univ Arkansas; Sam M Walton Coll Business & 2169 & 11 \\
\hline 13 & Univ British Columbia; Fac Commerce \& Business Adm & 2167 & 26 \\
\hline 14 & Univ Georgia; Terry Coll Business & 2022 & 38 \\
\hline 15 & Penn State Univ; Sch Informat Sci \& Technol & 2017 & 56 \\
\hline 16 & Florida State Univ; Coll Business & 2008 & 36 \\
\hline 17 & Georgia State Univ; Coll Business Adm & 1967 & 24 \\
\hline 18 & Harvard Univ; Sch Publ Hlth & 1707 & 38 \\
\hline 19 & Univ Illinois; Grad Sch Lib \& Informat Sci & 1669 & 167 \\
\hline 20 & Wolverhampton Univ; Sch Comp \& Informat Technol & 1669 & 109 \\
\hline 21 & Univ Tampere; Dept Informat Studies & 1621 & 96 \\
\hline 22 & City Univ London; Dept Informat Sci & 1580 & 192 \\
\hline 23 & Drexel Univ; Coll Informat Sci \& Technol & 1535 & 101 \\
\hline 24 & Univ Tennessee; Sch Informat Sci & 1488 & 118 \\
\hline 25 & City Univ Hong Kong; Dept Informat Syst & 1459 & 64 \\
\hline 26 & Univ So Calif; Marshall Sch Business & 1446 & 28 \\
\hline 27 & Georgia State Univ; Robinson Coll Business & 1421 & 25 \\
\hline 28 & Univ Calif Irvine; Grad Sch Management & 1385 & 25 \\
\hline 29 & Univ Western Ontario; Fac Informat \& Media Studies & 1332 & 138 \\
\hline 30 & Univ S Florida; Coll Business Adm & 1233 & 17 \\
\hline 31 & Univ N Carolina; Sch Lib \& Informat Sci & 1180 & 102 \\
\hline 32 & Syracuse Univ; Sch Informat Studies & 1178 & 162 \\
\hline 33 & Stanford Univ; Sch Med & 1162 & 76 \\
\hline 34 & Univ Penn; Wharton Sch & 1141 & 49 \\
\hline 35 & Georgia State Univ; Dept Comp Informat Syst & 1076 & 27 \\
\hline 36 & Brigham \& Womens Hosp; Div Gen Med \& Primary Care & 1074 & 16 \\
\hline 37 & Univ N Carolina; Kenan Flagler Business Sch & 1064 & 13 \\
\hline 38 & McGill Univ; Fac Management & 1063 & 20 \\
\hline 39 & Univ Western Ontario; Sch Business Adm & 1056 & 2 \\
\hline 40 & Carnegie Mellon Univ; Grad Sch Ind Adm & 1046 & 15 \\
\hline
\end{tabular}


We did not make an attempt to disambiguate and/or unify the names of institutions and suborganizations, but we used them as they were in WoS data. Instead, we tried to estimate the share of possible duplicate departments. The easiest way to do so was to calculate the similarities of all department names in three random samples of 500 departments using a well known algorithm and then manually check the department pairs whose similarity reached a certain threshold. The determined share of duplicate departments was always below $1 \%$. Thus, we believe that the absence of name disambiguation and unification (which is a very time-consuming task) does not significantly affect the results of this study.

Figure 5. Most intense collaborations between "LIS" departments.

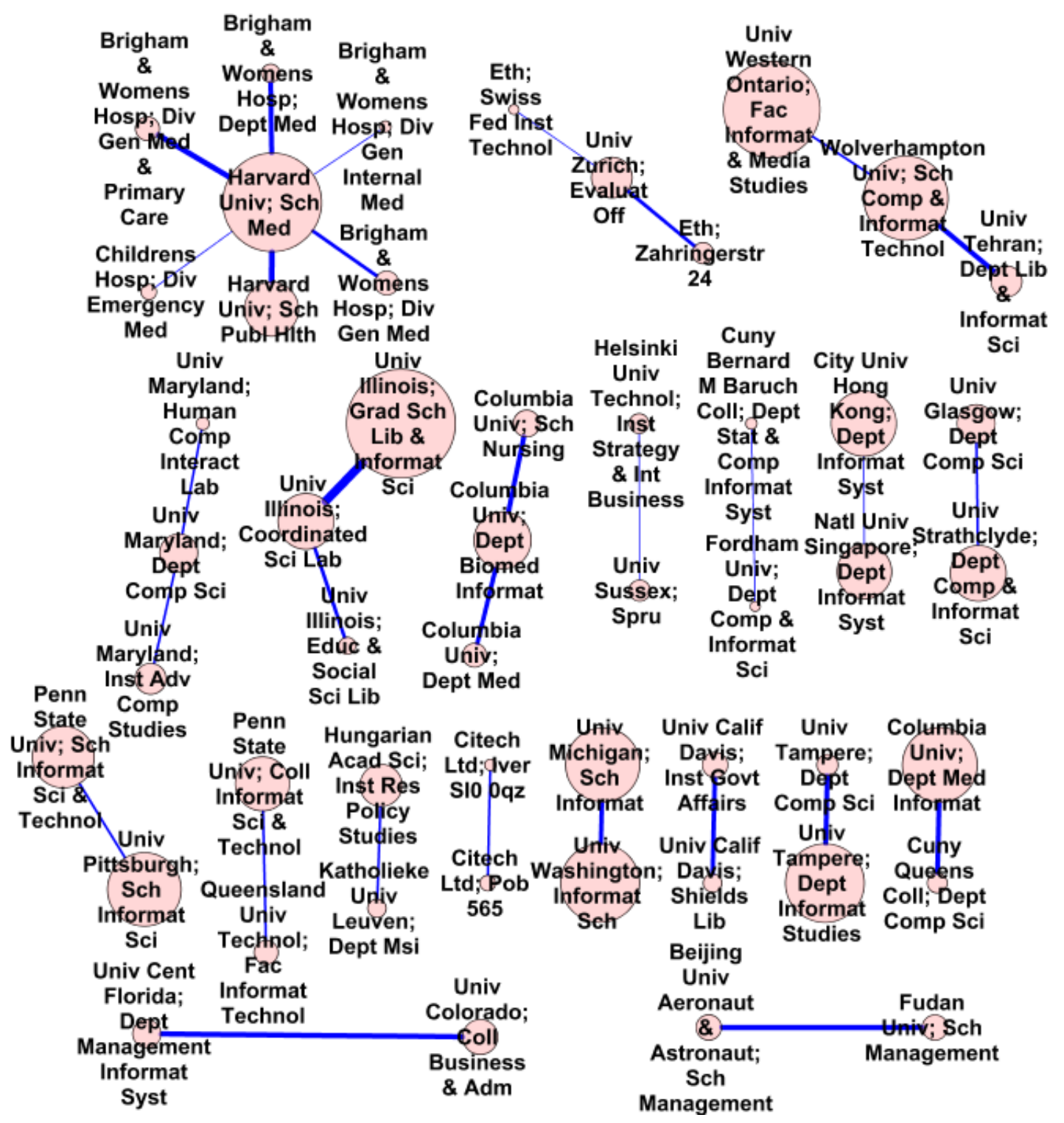

Apart from citations, we can also inspect collaboration patterns. The most intense collaborations between departments are depicted in Figure 5, where the node size depends on the publication count of a department and the edge thickness depends on the number of collaborations. The three most intense collaborations occur between "Univ Illinois; Coordinated Sci Lab" and "Univ Illinois; Grad Sch Lib \& Informat Sci" (an intra-institutional collaboration), "Brigham \& Womens Hosp; Div Gen Med \& 
Primary Care" and "Harvard Univ; Sch Med", and "Harvard Univ; Sch Med" and "Harvard Univ; Sch Publ Hlth" (also an intra-institutional collaboration). "Harvard Univ; Sch Med" is the "centre" of the biggest community in Figure 5 collaborating with four "Brigham \& Womens Hosp" departments, with another "Harvard Univ" department, and with "Childrens Hosp; Div Emergency Med". The share of intra-institutional interactions is substantially greater with collaborations than with citations-we found that almost $22 \%$ of all 22,569 collaborations were intra-institutional. As for the strength of the relationship between citations and collaborations, it does not seem meaningful to draw any conclusions from our data since only about $6 \%$ of collaborations occurred more than once and only about $1.5 \%$ of citations occurred more than ten times.

In addition to the rankings by citations or times cited, we created also other rankings of "LIS" departments based on other indicators: Publications (by the number of publications), Indegree (like citations but with all weights in the citation graph of departments set to 1), AvgTimesCited (average times cited per publication), HindexByTimesCited (h-index as defined by Hirsch [15] and based on times cited), HindexByEdges (based on citations within the graph), HITS [16], PageRank [17], and Weighted PageRank [18]. From these other eight rankings we only show the top 40 departments by PageRank and weighted PageRank in Table 4 and Spearman's rank correlations between all the rankings in Table 5 (all significant at the 0.01 leveltwo-tailed).

The PageRank and weighted PageRank rankings are the most highly correlated rankings of all with a rank correlation coefficient of 0.996 and also the first difference in the rankings is at rank 5, where there is "Haifa Univ; Dept Geog" by PageRank and "Univ Minnesota; Carlson Sch Management" by the weighted PageRank. Otherwise, the rankings in Table 4 are quite similar to each other but less so to the ranking by citations (correlation about 0.83 ) and even less to the ranking by times cited (around 0.69). PageRank-like algorithms (and also HITS) are iterative recursive methods dependent on the structure of the citation graph of departments and, therefore, they are much more related to citations than to times cited. Although the top departments shown in Table 4 do not resemble those in Tables 2 and 3, the overall rankings are still quite strongly correlated with all other rankings except Publications. The least correlation we found between Publications and AvgTimesCited - only about 0.2 Publications is also the most distant ranking from all others with an average correlation of 0.483 .

Finally, to conclude the section on results, in Table 6 we present examples of the most influential departments (by times cited) of four leading universities having the greatest times cited counts in our LIS data set. These universities are "Univ Maryland", "Indiana Univ", "Georgia State Univ", and "Univ Minnesota". We can notice that there are basically two types of performance distribution at institutions-either there is one dominant department like "Carlson Sch Management" at "Univ Minnesota" or "Robert H Smith Sch Business" at "Univ Maryland" or, to a lesser extent, "Sch Lib \& Informat Sci" at "Indiana Univ", or there are several comparably well performing departments like "Coll Business Adm", "Robinson Coll Business", and "Dept Comp Informat Syst" at "Georgia State Univ". Even if this example is small, we can assume that all influential institutions whose research influence is investigated at the level of departments can fit into one of these two basic performance distribution schemes. 
Table 4. Top 40 "LIS" departments by PageRank and weighted PageRank.

\begin{tabular}{|c|c|c|}
\hline & PageRank & Weighted PageRank \\
\hline 1 & Inst Studies Res \& Higher Educ; Munthes Gt 29 & Inst Studies Res \& Higher Educ; Munthes Gt 29 \\
\hline 2 & Norwegian Radium Hosp; Inst Canc Res & Norwegian Radium Hosp; Inst Canc Res \\
\hline 3 & Univ Missouri; Med Informat Grp & Univ Missouri; Med Informat Grp \\
\hline 4 & Univ Missouri; Program Hlth Serv Management & Univ Missouri; Program Hlth Serv Management \\
\hline 5 & Haifa Univ; Dept Geog & Univ Minnesota; Carlson Sch Management \\
\hline 6 & Univ Maryland; Dept Geog & Indiana Univ; Sch Lib \& Informat Sci \\
\hline 7 & Enea; Cr Casaccia & Haifa Univ; Dept Geog \\
\hline 8 & Univ Washington; Coll Educ & Univ Hull; Inst European Publ Law \\
\hline 9 & $\begin{array}{l}\text { Washington State Univ; Edward R Murrow Sch } \\
\text { Commun }\end{array}$ & Univ Hull; Sch Law \\
\hline 10 & Cornell Univ; Coll Agr \& Life Sci & Rutgers State Univ; Sch Commun Informat \& Lib Studies \\
\hline 11 & Cornell Univ; Coll Vet Med & Enea; Cr Casaccia \\
\hline 12 & Univ Hull; Sch Law & Univ Maryland; Dept Geog \\
\hline 13 & Univ Hull; Inst European Publ Law & Univ Washington; Coll Educ \\
\hline 14 & Univ Minnesota; Carlson Sch Management & Univ Sheffield; Dept Informat Studies \\
\hline 15 & Enea; Res Ctr Casaccia & Cornell Univ; Coll Vet Med \\
\hline 16 & Univ Hamburg; Inst Ethnol & Queens Univ; Sch Business \\
\hline 17 & Univ Calabria; Ctr Ingn Econ \& Sociale & Leiden Univ; Ctr Sci \& Technol Studies \\
\hline 18 & Enea; Ente Nuove Tecnol Energia Ambiente & Cornell Univ; Coll Agr \& Life Sci \\
\hline 19 & Indiana Univ; Sch Lib \& Informat Sci & Washington State Univ; Edward R Murrow Sch Commun \\
\hline 20 & $\begin{array}{l}\text { Rutgers State Univ; Sch Commun Informat \& Lib } \\
\text { Studies }\end{array}$ & Univ British Columbia; Fac Commerce \& Business Adm \\
\hline 21 & Queens Univ; Sch Business & Penn State Univ; Sch Informat Sci \& Technol \\
\hline 22 & Univ Vermont; Sch Business Adm & Univ Illinois; Grad Sch Lib \& Informat Sci \\
\hline 23 & Univ Sheffield; Dept Informat Studies & Univ Maryland; Robert H Smith Sch Business \\
\hline 24 & Univ Virginia; Mcintire Sch Commerce & Harvard Univ; Sch Med \\
\hline 25 & Leiden Univ; Ctr Sci \& Technol Studies & Enea; Res Ctr Casaccia \\
\hline 26 & Univ Maryland; Hlth Sci Lib & Univ Tennessee; Sch Informat Sci \\
\hline 27 & Univ Illinois; Grad Sch Lib \& Informat Sci & Univ Vermont; Sch Business Adm \\
\hline 28 & Univ Michigan; Alfred Taubman Med Lib & Univ Virginia; Mcintire Sch Commerce \\
\hline 29 & Univ Texas; Grad Sch Business & Univ Penn; Wharton Sch \\
\hline 30 & Harvard Univ; Sch Med & Univ Tampere; Dept Informat Studies \\
\hline 31 & $\begin{array}{l}\text { Natl \& Univ Lib Iceland; Interlib Loans Document } \\
\text { Delivery Dept }\end{array}$ & Univ Calif Irvine; Grad Sch Management \\
\hline 32 & Reykjavik Univ; European Documentat Ctr & Univ Maryland; Hlth Sci Lib \\
\hline 33 & Georgia State Univ; Coll Business Adm & Georgia State Univ; Coll Business Adm \\
\hline 34 & Univ Western Ontario; Sch Business Adm & Univ Georgia; Terry Coll Business \\
\hline 35 & Univ Calif Irvine; Grad Sch Management & Carnegie Mellon Univ; Grad Sch Ind Adm \\
\hline 36 & $\begin{array}{l}\text { Univ British Columbia; Fac Commerce \& Business } \\
\text { Adm }\end{array}$ & City Univ London; Dept Informat Sci \\
\hline 37 & Syracuse Univ; Sch Informat Studies & Univ Michigan; Alfred Taubman Med Lib \\
\hline 38 & Univ Michigan; Head Hlth Sci Lib & Univ N Carolina; Sch Lib \& Informat Sci \\
\hline 39 & Oregon State Univ; Dept Journalism & Drexel Univ; Coll Informat Sci \& Technol \\
\hline 40 & Carnegie Mellon Univ; Grad Sch Ind Adm & Syracuse Univ; Sch Informat Studies \\
\hline
\end{tabular}


Table 5. Spearman's rank correlation coefficients between various rankings.

\begin{tabular}{|c|c|c|c|c|c|c|c|c|c|c|}
\hline & $\begin{array}{c}\text { Avg } \\
\text { Times } \\
\text { Cited } \\
\end{array}$ & Citations & Indegree & Publications & $\begin{array}{l}\text { Times } \\
\text { Cited }\end{array}$ & $\begin{array}{c}\text { Hindex } \\
\text { By } \\
\text { Edges }\end{array}$ & $\begin{array}{c}\text { Hindex } \\
\text { ByTims } \\
\text { Cited }\end{array}$ & HITS & PR & $\begin{array}{c}\text { PR } \\
\text { weighted }\end{array}$ \\
\hline $\begin{array}{l}\text { Avg } \\
\text { TimesCited }\end{array}$ & 1 & 0.7009 & 0.7055 & 0.2045 & 0.9513 & 0.6944 & 0.7048 & 0.6785 & 0.6358 & 0.6340 \\
\hline Citations & 0.7009 & 1 & 0.9908 & 0.4360 & 0.7641 & 0.7805 & 0.6355 & 0.9604 & 0.8300 & 0.8342 \\
\hline Indegree & 0.7055 & 0.9908 & 1 & 0.4270 & 0.7653 & 0.7790 & 0.6312 & 0.9623 & 0.8416 & 0.8385 \\
\hline Publications & 0.2045 & 0.4360 & 0.4270 & 1 & 0.4561 & 0.4974 & 0.6126 & 0.4052 & 0.3917 & 0.3981 \\
\hline TimesCited & 0.9513 & 0.7641 & 0.7653 & 0.4561 & 1 & 0.7765 & 0.8224 & 0.7352 & 0.6918 & 0.6923 \\
\hline $\begin{array}{l}\text { Hindex } \\
\text { ByEdges }\end{array}$ & 0.6944 & 0.7805 & 0.7790 & 0.4974 & 0.7765 & 1 & 0.7879 & 0.7648 & 0.6881 & 0.6887 \\
\hline $\begin{array}{l}\text { Hindex } \\
\text { ByTimesCited }\end{array}$ & 0.7048 & 0.6355 & 0.6312 & 0.6126 & 0.8224 & 0.7879 & 1 & 0.6153 & 0.5978 & 0.6011 \\
\hline HITS & 0.6785 & 0.9604 & 0.9623 & 0.4052 & 0.7352 & 0.7648 & $3^{0.615}$ & 1 & $020^{0.8}$ & 0.7999 \\
\hline PR & 0.6358 & 0.8300 & 0.8416 & 0.3917 & 0.6918 & 0.6881 & 0.5978 & 0.8020 & 1 & 0.9958 \\
\hline PR weighted & 0.6340 & 0.8342 & 0.8385 & 0.3981 & 0.6923 & 0.6887 & 0.6011 & 0.7999 & 0.9958 & 1 \\
\hline
\end{tabular}

Table 6. Top 20 "LIS" departments of four leading universities by times cited.

\begin{tabular}{llll}
\hline \multicolumn{1}{c}{ Univ Maryland } & & \multicolumn{1}{c}{ Indiana Univ } \\
\hline Robert H Smith Sch Business & 3860 & Sch Lib \& Informat Sci & 3475 \\
Rh Smith Sch Business & 755 & Kelley Sch Business & 1035 \\
Coll Lib \& Informat Serv & 597 & Sch Med & 709 \\
Coll Informat Studies & 565 & Sch Business & 254 \\
Asian Div & 480 & Dept Telecommun & 227 \\
Coll Business \& Management & 407 & Slis & 221 \\
Dept Decis \& Informat Technol & 387 & Grad Sch Business & 213 \\
Dept Comp Sci & 221 & Ctr Social Informat & 142 \\
Coll Lib \& Informat Sci & 151 & Sch Publ \& Environm Affairs & 141 \\
Inst Adv Comp Studies & 145 & Kelly Sch Business & 121 \\
Dept Informat Syst & 136 & Sch Informat & 89 \\
Dept Geog & 123 & Sch Educ & 70 \\
Sch Med & 100 & Regenstrief Inst Hlth Care & 62 \\
Human Comp Interact Lab & 96 & Sch Journalism & 51 \\
Amer Use Time Project & 72 & Dept Geog & 44 \\
Joint Program Survey Methodol & 69 & Inst Commun Res & 38 \\
Ctr Comp Sci & 65 & Dept Instruct Syst Technol & 35 \\
College Pk & 62 & Dept Polit Sci & 26 \\
Rh Smith Sch & 62 & Dept Amer Studies & 24 \\
Hlth Sci Lib & 58 & Roudebush Va Med Ctr & 21 \\
\hline
\end{tabular}


Table 6. Cont.

\begin{tabular}{lcll}
\hline \multicolumn{1}{c}{ Georgia State Univ } & \multicolumn{2}{c}{ Univ Minnesota } \\
\hline Coll Business Adm & 1967 & Carlson Sch Management & 4756 \\
Robinson Coll Business & 1421 & Curtis L Carlson Sch Management & 609 \\
Dept Comp Informat Syst & 1076 & Dept Informat \& Decis Sci & 100 \\
J Mack Robinson Coll Business & 697 & Sch Journalism \& Mass Commun & 91 \\
Comp Informat Syst Dept & 675 & Mis Res Ctr & 66 \\
Robinbson Coll Business & 220 & Dept Geog & 46 \\
Dept Management & 210 & Sch Law & 40 \\
Ctr Proc Innovat \& Comp Informat Syst & 194 & Digital Technol Ctr & 38 \\
Ctr Proc Innovat & 119 & Informat \& Decis Sci Dept & 35 \\
Coll Business & 77 & Biomed Lib & 32 \\
J Mack Robinson Coll Business Adm & 45 & Dept Psychol & 30 \\
Cis Dept & 40 & E Asian Lib & 24 \\
Business Adm & 36 & Coll Educ \& Human Dev & 23 \\
Dept Comp Informat Ssyt & 36 & St Paul Campus Lib & 18 \\
Dept Commun & 34 & Dept Comp Sci \& Engn & 17 \\
Policy Res Ctr & 24 & Sch Med & 17 \\
Coll Educ & 12 & Sch Nursing & 14 \\
Pullen Lib & 11 & 1445 Gortner Ave & 13 \\
William Russell Pullen Lib & 11 & Sci \& Engn Lib & 13 \\
Dept Sociol & 8 & Walter Lib 108 & 13 \\
\hline
\end{tabular}

\section{Conclusions and Future Work}

Most large-scale scientometric research at the meso-level is concerned with primary research organizations (institutions), but only few studies analyze the scientific impact and collaboration of the suborganizations of these institutions. These suborganizations can be called schools, departments, divisions, laboratories, etc. and they themselves may be divided into further suborganizations of lower levels in the organizational hierarchy of an institution. Varying organizational structures along with ambiguities in the names of suborganizations may be the reason of the lack of large-scale scientometric analyses at the level of departments. This article tries to bridge this gap in the field of library and information science. The main contributions of this study are the following:

- We analyzed the bibliographic records of 46,800 journal articles indexed in the Web of Science category "Information Science \& Library Science" that were published between 1991 and 2010.

- We created citation and collaboration networks of level-1 suborganizations that we call departments and we visualized the most intense citations and collaborations between departments.

- We produced various rankings of "LIS" departments using ten well-known methods and computed the correlations between these rankings.

The main findings of our study confirm the sufficiency of WoS data and are as follows:

- Almost $88 \%$ of publications had some address information associated with them, but prior to 1998 only few publications had other than reprint addresses included. 
- "Indiana Univ; Sch Lib \& Informat Sci" is the best department in terms of citations and "Univ Minnesota; Carlson Sch Management" is ranked first by times cited.

- Most cited of all departments is "Indiana Univ; Sch Lib \& Informat Sci" by "Wolverhampton Univ; Sch Comp \& Informat Technol" and the most intense departmental collaboration occurs between "Univ Illinois; Coordinated Sci Lab" and "Univ Illinois; Grad Sch Lib \& Informat Sci".

In our future work on the scientific performance and collaboration at the level of departments, we would like focus on other fields of science, other publication sources (e.g., conference proceedings), and other time periods.

\section{Acknowledgments}

This work was supported by the European Regional Development Fund (ERDF), project "NTIS-New Technologies for Information Society", European Centre of Excellence, CZ.1.05/1.1.00/02.0090.

\section{Conflicts of Interest}

The author declares no conflict of interest.

\section{References}

1. Bradley, S.J.; Willett, P.; Wood, F.E. Publication and citation analysis of the department of information studies, University of Sheffield, 1980-1990. J. Inf. Sci. 1992, 18, 225-232.

2. Holmes, A.; Oppenheim, C. Use of citation analysis to predict the outcome of the 2001 research assessment exercise for unit of assessment (UoA) 61: Library and information management. Inf. Res. 2001, 6. Available online: http://InformationR.net/ir/6-2/paper103.html (accessed on 5 October 2013).

3. Oppenheim, C. The correlation between citation counts and the 1992 research assessment exercise ratings for British library and information science university departments. J. Doc. 1995, 51, $18-27$.

4. Seng, L.B.; Willett, P. The citedness of publications by United Kingdom library schools. J. Inf. Sci. 1995, 21, 68-71.

5. Webber, S. Information science in 2003: A critique. J. Inf. Sci. 2003, 29, 311-330.

6. Thomas, O.; Willett, P. Webometric analysis of departments of librarianship and information science. J. Inf. Sci. 2000, 26, 421-428.

7. Arakaki, M.; Willett, P. Webometric analysis of departments of librarianship and information science: A follow-up study. J. Inf. Sci. 2009, 35, 143-152.

8. Aina, L.O.; Mooko, N.P. Research and publication patterns in library and information science. Inf. Dev. 1999, 15, 114-119.

9. Herrero-Solana, V.; Ríos-Gómez, C. Producción latinoamericana en biblioteconomía y documentación en el social science citation index (SSCI) 1966-2003. Inf. Res. 2006, 11, 21-45, (in Spanish). 
10. Meho, L.I.; Spurgin, K.M. Ranking the research productivity of library and information science faculty and schools: An evaluation of data sources and research methods. J. Am. Soc. Inf. Sci. Technol. 2005, 56, 1314-1331.

11. Yazit, N.; Zainab, A.N. Publication productivity of Malaysian authors and institutions in LIS. Malays. J. Libr. Inf. Sci. 2007, 12, 35-55.

12. Yan, E.; Sugimoto, C.R. Institutional interactions: Exploring social, cognitive, and geographic relationships between institutions as demonstrated through citation networks. J. Am. Soc. Inf. Sci. Technol. 2011, 62, 1498-1514.

13. He, B.; Ding, Y.; Yan, E. Mining patterns of author orders in scientific publications. J. Informetr. 2012, 6, 359-367.

14. Shannon, P.; Markiel, A.; Ozier, O.; Baliga, N.S.; Wang, J.T.; Ramage, D.; Amin, N.; Schwikowski, B.; Ideker, T. Cytoscape: A software environment for integrated models of biomolecular interaction networks. Genome Res. 2003, 13, 2498-2504.

15. Hirsch, J.E. An index to quantify an individual's scientific research output. Proc. Natl. Acad. Sci. USA 2005, 102, 16569-16572.

16. Kleinberg, J.M. Authoritative sources in a hyperlinked environment. J. ACM 1999, 46, 604-632.

17. Brin, S.; Page, L. The anatomy of a large-scale hypertextual Web search engine. Comput. Netw. ISDN Syst.1998, 30, 107-117.

18. Fiala, D. Time-aware PageRank for bibliographic networks. J. Informetr. 2012, 6, 370-388.

(C) 2013 by the authors; licensee MDPI, Basel, Switzerland. This article is an open access article distributed under the terms and conditions of the Creative Commons Attribution license (http://creativecommons.org/licenses/by/3.0/). 